\title{
The Influence of Sales Promotion, Product Quality and Customer Satisfaction on Customer Loyalty at PT. Salim Jaya Medan (A Case Study of Frozen Food Distribution)
}

\author{
Hengky $^{1}$, Marke Wijaya ${ }^{2}$, Tri Wahyuni Wijaya ${ }^{3}$, Irene $^{4}$, Hendry $^{5}$ \\ $1,2,3,4,5$ Universitas Prima Indonesia \\ yuniiwijayya@gmail.com
}

\begin{abstract}
The object of this research was conducted at PT. Salim Jaya Medan, a company that is active as a distributor of frozen food, especially for raw materials for seafood and local and imported meat. In this company, the number of customers is decreasing from time to time. This is thought to be due to sales promotion factors, product quality and customer satisfaction. The research method used by researchers is quantitative, the type of research is descriptive. Primary and secondary data were used. The data collection technique is done by interview, questionnaire and documentation study. The data analysis used was multiple linear regressions, the coefficient of determination of simultaneous testing ( $F$-test), and partial testing ( $t$-test). The study population was 109 customers of PT. Salim Jaya Medan where 30 people were used as validity testing while the research sample was 86 people. The partial test results show that sales promotion, product quality and customer satisfaction have a positive effect on customer loyalty, while simultaneously it shows that sales promotion and customer satisfaction have a positive and significant effect on customer loyalty.
\end{abstract}

Keywords

sales promotion; product quality, customer satisfaction; customer loyalty

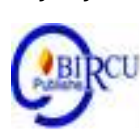

\section{Introduction}

Economic growth is still an important goal in a country's economy, especially for developing countries like Indonesia. Economic growth must also be followed by positive changes in the context of improving the welfare and prosperity of the people who are mandated by the 1945 Constitution. Therefore, economic development is still the focus of development in Indonesia and is an indication of the success of development. Economic growth is a process of increasing the production capacity of an economy that is realized in the form of an increase in national and regional income. (Magdalena, 2020)

Customer loyalty is very important for companies in this era of very tight business competition. The importance of customer loyalty to the company is beyond doubt, many companies really hope to retain their customers in the long term, even if possible forever. Companies that are able to develop and maintain customer loyalty will have long-term success. The company observes the factors that can affect customer loyalty, including sales promotion, product quality and customer satisfaction.

PT. Salim Jaya Medan is a company that is active as a distributor of frozen food, especially for raw materials for seafood and local and imported meats. Sales promotion is one of the promotional activities carried out by a company to sell the products it markets by placing and certain arrangements so that consumers can easily see and find out what products the company sells, so that consumers can be interested and decide to make a purchase. 
A company that has planned a product with good quality, and has determined the selling price correctly, has not guaranteed success in marketing its product. For that, there is a need for communication between the company and its consumers. One effort that can be used to introduce a company's products or services is to use promotional activities of several types, such as advertising, personal selling, sales promotion and publicity.

Based on the information collected by researchers, it is known that the number of subscribers has decreased from time to time. This can be seen in the data on the number of customers from 2016 to 2018 below:

Table 1. Number of Customers PT. Salim Jaya Medan in 2018

\begin{tabular}{|l|c|c|c|}
\hline \multirow{2}{*}{ Month } & \multicolumn{3}{|c|}{ Number of Customers } \\
\cline { 2 - 4 } & $\begin{array}{c}2016 \\
\text { year }\end{array}$ & $\begin{array}{c}2017 \\
\text { year }\end{array}$ & $\begin{array}{c}2018 \\
\text { year }\end{array}$ \\
\hline Januari & 243 & 245 & 232 \\
\hline Februari & 252 & 276 & 205 \\
\hline Maret & 264 & 284 & 179 \\
\hline April & 265 & 277 & 131 \\
\hline Mei & 284 & 269 & 135 \\
\hline Juni & 278 & 281 & 117 \\
\hline Juli & 256 & 281 & 117 \\
\hline Agustus & 248 & 285 & 106 \\
\hline September & 251 & 265 & 126 \\
\hline Oktober & 251 & 230 & 122 \\
\hline November & 251 & 256 & 116 \\
\hline Desember & 234 & 233 & 109 \\
\hline
\end{tabular}

Source: PT. Salim Jaya Medan (2019)

The decline in the number of subscribers to 109 people in 2018 compared to the previous year can be said to be quite drastic. The decrease in the number of customers is due to customers switching to other competing companies. This indicates a customer loyalty problem. Furthermore, the researchers also obtained information that there was a decrease in the frequency of procurement of sales promotions, such as reduced discounts, less economical installment packages, and a reduction in lucky draw programs for customers. Another phenomenon that was found was customer dissatisfaction, this can be seen in the following table:

Table 2. Complaint Data that Shows Customer Dissatisfaction

\begin{tabular}{|c|l|c|l|}
\hline No. & Year & Number of Complaints & \multicolumn{1}{c|}{ Descripion } \\
\hline 2016 & 11 & $\begin{array}{l}\text { 1. Complaints about service from employees. } \\
\text { 2. Late delivery of goods. }\end{array}$ \\
\hline 2. & 2017 & 18 & $\begin{array}{l}\text { 1. Many cases of customers are not satisfied } \\
\text { because of late delivery of goods. } \\
\text { 2. The quality of the items was a little } \\
\text { disappointing }\end{array}$ \\
\hline
\end{tabular}




\begin{tabular}{|l|l|l|l|}
\hline 3.2018 & 35 & $\begin{array}{l}\text { 1. There are many cases of consumer } \\
\text { disappointment with the failure of the } \\
\text { company's promise to deliver goods. } \\
\text { 2. }\end{array}$ & $\begin{array}{l}\text { Decreased consumer assessment of company } \\
\text { attitudes in response to consumer questions. } \\
\text { 3. The quality of the goods has deteriorated. }\end{array}$ \\
\hline
\end{tabular}

Source: Short Interview with PT. Salim Jaya Medan (2019)

Reviewing the problems that occur in the company, the researcher took the initiative to conduct a study entitled "The Effect of Sales Promotion, Product Quality and Customer Satisfaction on Customer Loyalty at PT. Salim Jaya Medan (Case Study of Frozen Food Distribution)".

Based on the above background, it is alleged that the problems that occur in this company are as follows:

1. There is a decrease in customer loyalty due to the frequency of sales promotions that are rarely carried out.

2. There is a decrease in customer loyalty due to the slightly disappointing sales product quality.

3. There is a decrease in customer loyalty caused by customer satisfaction as seen from the number of customers who expressed disappointment.

Researchers limit this research only to sales promotion $\left(\mathrm{X}_{1}\right)$, product quality $\left(\mathrm{X}_{2}\right)$ and customer satisfaction $\left(\mathrm{X}_{3}\right)$ and their effect on customer loyalty (Y) PT. Salim Jaya Medan.

In accordance with the background of the problem that has been stated, the problem formulations in this study are:

1. How is the effect of sales promotions on customer loyalty at PT. Salim Jaya Medan?

2. How is the influence of product quality on customer loyalty at PT. Salim Jaya Medan?

3. How does the influence of customer satisfaction on customer loyalty at PT. Salim Jaya Medan?

4. How to influence sales promotion, product quality and customer satisfaction together on customer loyalty at PT. Salim Jaya Medan?

The objectives of this research are as follows:

1. To determine the effect of sales promotions on customer loyalty at PT. Salim Jaya Medan.

2. To determine the effect of product quality on customer loyalty at PT. Salim Jaya Medan.

3. To determine the effect of customer satisfaction on customer loyalty at PT. Salim Jaya Medan.

4. To determine the effect of sales promotion, product quality and customer satisfaction together on customer loyalty at PT. Salim Jaya Medan.

\section{Review of Literatures}

\subsection{Customer Loyalty}

The economy is a very important sector and is one of the focuses of the government in making various policies to achieve prosperity. So important is this economic sector that in every policy making must consider all aspects that may affect both positive and negative. The economy in Indonesia currently uses a populist economic system where the economic system is based on the strength of the people's economy, where the community holds an active role in economic activities, while the government creates a healthy climate for the growth and development of the business world. (Rosmika, 2019) 
The development of business organizations can be realized if supported by two very significant factors, namely customer satisfaction and loyalty for the products we produce. The greater the satisfaction received by consumers and the higher the value of customer loyalty, the greater the profits the company will get (Romdonny, 2019).

Customer loyalty is purchasing behavior which can be defined as nonrandom purchases that are expressed from time to time by several decision-making units (Griffin, 2005). According to Kottler and Keller (2012), customer loyalty is a customer's willingness to continue to buy from a company in the long run and recommend products to friends and colleagues, including preferences, wishes and future intentions

Customer loyalty occurs when the customer's assessment of the quality of a product or service is high (superior), the customer's behavioral intentions will be favorable (positive), that is, trying to strengthen relationships with a product, for example: stating positive things about the product, staying loyal to the product recommend the product to others. Increase the volume of his purchases or be willing to pay a premium price. Customers who perceive service quality as inferior are likely to exhibit certain behaviors. Like, cutting ties with these products, spending less on these products, and complaining. These behavioral intentions will indicate whether the customer will remain loyal (loyal) or move (Rangkuti, 2010).

\subsection{Sales Promotion}

Promotion is seen as a one-way flow of persuasion or information that directs a person or organization to actions that create exchange in society. So promotion is one of the important aspects in marketing management and is often said to be a continuous process, because promotion can lead to the next series of activities of the company (Private, 2004). Promotion strategy is very important for companies where marketing strategy is a way to achieve the goals of a company. This is also supported by the opinion of Private (2004) that strategy is "a series of grand designs that describe how a company must operate to achieve its goals". So that in running a small business, in particular, it requires development through its marketing strategy. Because when the condition is critical, it is precisely the small businesses that are able to provide growth in people's income.

According to Wood (2009: 199), "it takes time to build a brand, build customer loyalty, or reinforce commitment among members, but sales promotions can help reduce perceived prices or increase perceived value for a limited time. Tjiptono (2008: 229) explains that "the characteristics contained in a sales promotion include communication, incentives, and invitations. The nature of communication means that sales promotions are able to attract attention and provide information that introduces customers to the product.

\subsection{Definition of Product Quality}

Some quality experts define quality with various interpretations. According to Kotler and Armstrong (2006) product quality is the ability of a product to carry out its functions, including in this case the overall durability, reliability, and accuracy, level of ease of operation, repair and other valuable attributes. Dale (2003) states that product quality is a wider public perception of the quality of products and services, the increasing views and roles of top management, quality is not negotiable, quality is all-pervasive, quality is all-pervasive. Increasing productivity, quality affects better performance on the market, quality means improving business performance, high non-quality costs, and consumers are king, quality is a way of life. 


\subsection{Customer Satisfaction}

Daryanto and Setyabudi (2014: 52) explain that customer satisfaction is a feeling of satisfaction obtained by customers because they get value from suppliers, manufacturers, or service providers. This value can come from a product, service, system or something emotional. Tjiptono (2008: 24) explains that the notion of customer satisfaction includes the difference between expectations and performance or perceived results. Sangadji and Sopiah (2013: 180) suggest that the definition of satisfaction or dissatisfaction is the feeling of pleasure or disappointment of a person which comes from a comparison between his impressions of the real / actual product performance with the expected product performance.

\subsection{Customer Satisfaction}

There are 4 hypotheses in this study, namely:

H1:Sales promotion has a significant positive effect on customer loyalty at PT. Salim Jaya Medan

H2:Product quality has a significant positive effect on customer loyalty at PT. Salim Jaya Medan

H3:Customer satisfaction has a significant positive effect on customer loyalty at PT. Salim Jaya Medan

$\mathrm{H} 4$ :Sales promotion, product quality and customer satisfaction have a significant positive effect together on customer loyalty at PT. Salim Jaya Medan

\section{Research Methods}

\subsection{Types and Sources of Research}

This research approach is quantitative research. This type of research is descriptive research. Primary data in this study includes the results of filling out questionnaires distributed to respondents. Secondary data in this study include company profiles and literature and data related to the problem under study.

Sources of research data consist of:

1. Primary data sources

Primary data sources are sources of research data obtained directly from the original source (not through intermediary media).

2. Secondary data sources

Secondary data sources are sources of research data obtained by researchers indirectly through intermediary media (obtained and recorded by another party).

The primary data source in this research is the customers of PT. Salim Jaya Medan who was the respondent in filling out the questionnaire. Secondary sources are theoretical books which are used as research references along with company documentation.

\subsection{Population and Sample}

According to Sugiyono (2012: 117), "population is a generalization area consisting of objects / subjects that have certain qualities and characteristics that are determined by researchers to be studied and then draw conclusions." The population in this study were 109 customers of PT. Salim Jaya Medan (recorded in December 2017).

According to Sugiyono (2012: 118), "The sample is part of the number and characteristics of the population". Researchers used saturated sampling in which all members of the population were selected as the research sample. Widi (2010: 198) explains that "the sample must be a representative part of the population to be studied." The sample in this study used was obtained based on the Slovin technique. The results of calculations using the 
Solvin technique get the number 85.66 and rounded up to 86 samples. The sampling technique used in this study was simple random sampling. According to Gunawan (2015: 49), "simple random sampling or simple random sampling is a method of taking samples from members of the population using random without paying attention to the strata (levels) in the members of the population."

\subsection{Technique of Collection Data}

The data collection techniques used is:

1. Interview, by conducting direct questions and answers to the sales department to obtain information about sales promotions, customer satisfaction, and customer loyalty.

2. Questionnaire or questionnaire, by giving a set of questions or written statements to respondents to respond according to instructions. The measurement scale used is the Likert scale. Siregar (2014: 25) suggests that the Likert scale is a scale used to measure a person's attitudes, opinions and perceptions about a certain object or phenomenon.

3. Documentation, used to obtain data in connection with what is needed in this study.

\section{Result and Discussion}

\subsection{Normality Test}

The following is a table of normality test results from the Sales Promotion, Customer Satisfaction, and Customer Loyalty variables:

Table 3. Normality Test One-Sample Kolmogorov-Smirnov Test

\begin{tabular}{|ll|r|}
\hline & & \multicolumn{2}{|c|}{$\begin{array}{c}\text { Unstandardized } \\
\text { Predicted Value }\end{array}$} \\
\hline $\mathrm{N}$ & Mean & 86 \\
Normal Parameters & & 298.953 .488 \\
& Std. & 248.405 .156 \\
& Deviation & .070 \\
Most Extreme & Absolute & .056 \\
Differences & Positive & -.070 \\
Kolmogorov-Smirnov Z & Negative & .651 \\
Asymp. Sig. (2-tailed) & & .790 \\
\hline
\end{tabular}

a. Test distribution is Normal.

Source: Data processed by SPSS version 20.0 (2020)

Based on table IV-9 above, it can be seen that the sample data of 86 people are normally distributed. This is evidenced by the Asymp value. Sig. (2tailed) is greater than the value of $\alpha=0.05(0.790>0.05)$. Asymp Value. Sig. (2tailed) is an indication of the normality of the data compared with $\alpha=0.05$. If the value is Asymp. Sig. (2tailed) is smaller than $\alpha=$ 0.05 , then the data is not normally distributed, whereas if the Asymp value. Sig. (2tailed) is greater than the value of $\alpha=0.05$, so the data is normally distributed.

Another data normality assumption test used in this study is to use a graphical approach. Normality testing is used to see the distribution pattern of errors. This test can be done by looking at the bell-shaped error histogram graph (normal distribution) and the Normal P-P-plot. 


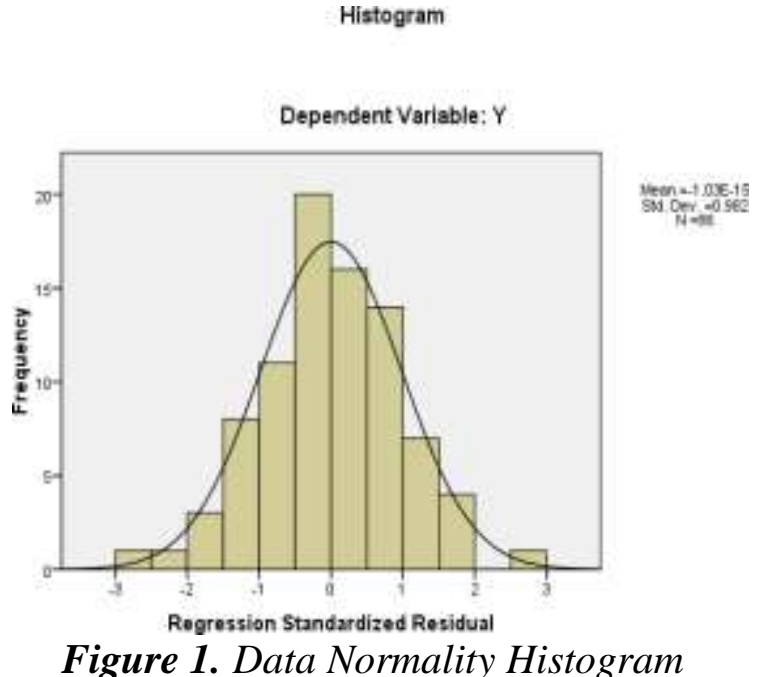

Source: Data processed by SPSS version 20.0 (2020)

Based on the table of SPSS output results above, the histogram diagram that is formed forms a normal curve, the residual is declared normal and the normality assumption is fulfilled.
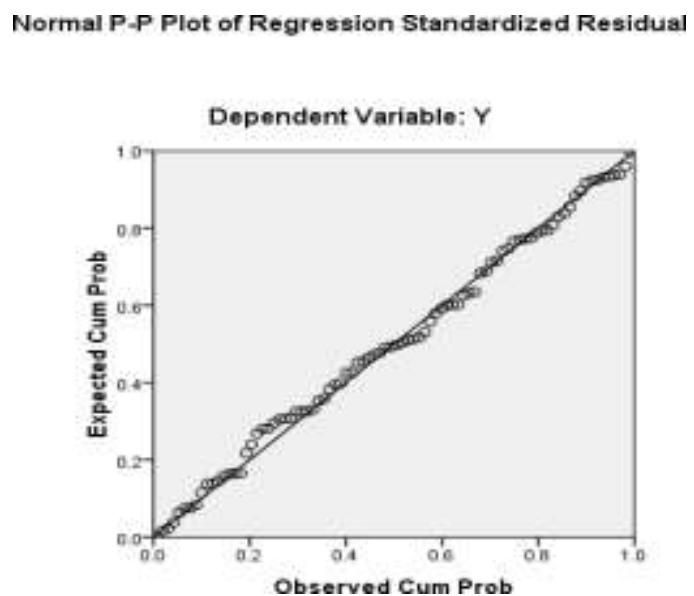

Figure 2. P-P Data Normality Plot

Source: Data processed by SPSS version 20.0 (2020)

From the picture above, it can be seen that the points or data are unidirectional and follow a diagonal line. It can be concluded that the data is normally distributed, so that it can proceed to the multicollinearity test.

\subsection{Multicollinearity Test}

Multicollinearity test is needed to determine whether there are independent variables that have between independent variables in a model. The multicollinearity test in this study was carried out by looking at the Variance Inflation Factor (VIF) and Tolerance values in the regression model. If the VIF value is less than 10 and the Tolerance is more than 0.1 , it is stated that there is no multicollinearity. The results of multicollinearity test data processing can be seen in the following table: 
Table 4. Multicollinearity Test Coefficients

\begin{tabular}{|ll|r|r|}
\hline \multirow{2}{*}{ Model } & \multicolumn{2}{|c|}{ Collinearity Statistics } \\
\cline { 2 - 4 } & Tolerance & \multicolumn{1}{c|}{ VIF } \\
\hline 1 & (Constant) & & \\
X1 & .650 & 1.539 \\
X2 & .647 & 1.540 \\
X3 & .662 & 1.512 \\
\hline
\end{tabular}

Source: Data processed by SPSS version 20.0

From the table above, it can be seen that the tolerance value of the sales promotion variable $\left(\mathrm{X}_{1}\right)=0.650>0.10$, product quality $\left(\mathrm{X}_{2}\right)=0.647>0.10$ and customer satisfaction $\left(\mathrm{X}_{3}\right)=0.662>0.10$ and so are the VIF values of $\mathrm{X}_{1}, \mathrm{X}_{2}$ and $\mathrm{X}_{3}<10$. So it can be concluded that in the regression between the independent variables $X_{1}, X_{2}$ and $X_{3}$ there is no multicollinearity between the independent variables and the variables meet the classical assumption test.

\subsection{Heteroscedasticity Test}

Heteroscedasticity testing to see the homogeneity between the residuals of the observed data. Testing can be done with a scatterplot graph approach and the following is a picture of the test results.

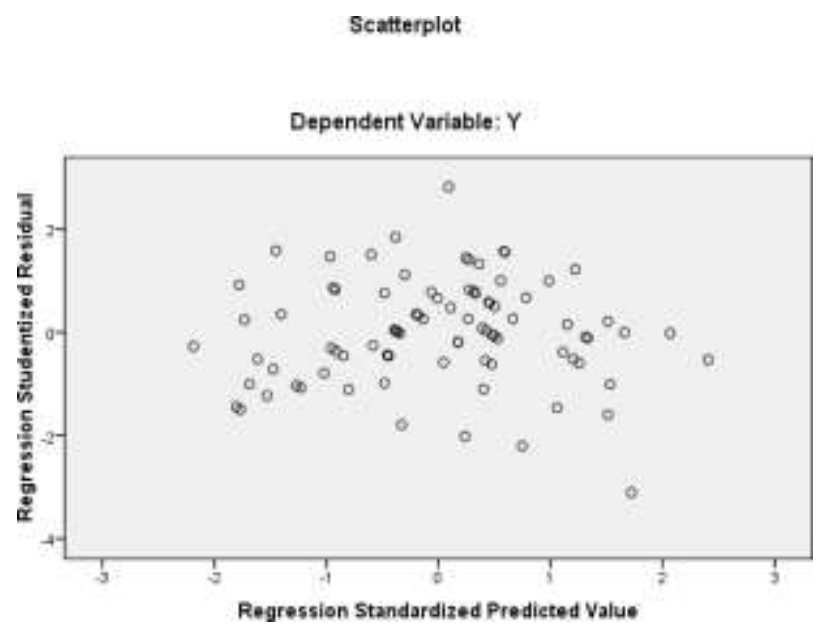

Figure 3. Heteroscedasticity Test Results

Source: Data processed by SPSS version 20.0 (2020)

From the picture above, it can be seen that the dots spread randomly and are scattered both above and below the number 0 on the $\mathrm{Y}$ axis. Sales promotion, product quality and customer satisfaction.

\subsection{Multiple Linear Regressions}

Multiple linear regression analysis is used to determine the effect of sales promotion, product quality and customer satisfaction on customer loyalty. In the process of calculating multiple linear regressions, the researcher uses the help of the SPSS version 20.0 program from the results of processing using SPSS, the following results are obtained: 
Table 5. Multiple Linear Regression

\begin{tabular}{|ll|r|r|r|r|r|}
\hline \multirow{2}{*}{ Model } & \multicolumn{3}{|c|}{$\begin{array}{c}\text { Unstandardized } \\
\text { Coefficients }\end{array}$} & $\begin{array}{c}\text { Standardized } \\
\text { Coefficients }\end{array}$ & \multirow{2}{*}{$\mathrm{t}$} & \multirow{2}{*}{ Sig. } \\
\cline { 2 - 4 } & \multicolumn{1}{|c|}{$\mathrm{B}$} & \multicolumn{1}{c|}{ Std. Error } & \multicolumn{1}{c|}{ Beta } & & \\
\hline 1 & (Constant) & 4.605 & 2.187 & & 2.106 & .038 \\
& .181 & .070 & .201 & 2.583 & .012 \\
& X1 & .226 & .074 & .237 & 3.044 & .003 \\
& X2 & .566 & .081 & .540 & 6.998 & .000 \\
\hline
\end{tabular}

a. Dependent Variable: Y

Source: Data processed by SPSS version 20.0

From the table above, it can be seen that the regression equation formed from the calculation is:

$$
Y=4.605+0.181 X_{1}+0.226 X_{2}+0,566 X_{3}
$$

From the above equation it can be interpreted as follows:

1. Constant (a) $=4.605$ This means that although the independent variable $\left(\mathrm{X}_{1}\right)$ is sales promotion, the independent variable $\mathrm{X}_{2}$ is product quality and the independent variable $\mathrm{X}_{3}$ is customer satisfaction with a value of 0 , then customer loyalty (Y) is still at 4.605.

2. The coefficient of $X_{1}\left(b_{1}\right)=0.181$ and is positive. This means that every time there is an increase in the sales promotion variable by 1 unit, then customer loyalty (Y) will increase by 0.181 .

3. The coefficient of $X_{2}\left(b_{2}\right)=0.226$ and is positive. This means that every time there is an increase in the product quality variable by 1 unit, then customer loyalty (Y) will increase by 0.226 .

4. The coefficient of $X_{3}\left(b_{3}\right)=0.566$ and is positive. This means that every time there is an increase in the customer satisfaction variable by 1 unit, then customer loyalty (Y) will increase by 0.566 .

\subsection{Hypothesis test}

a. Simultaneous Hypothesis Testing (Test F)

Table 6. F ANOVA Test Results

\begin{tabular}{|rl|r|r|r|r|r|}
\hline \multicolumn{1}{|c|}{ Model } & & \multicolumn{1}{c|}{$\begin{array}{c}\text { Sum of } \\
\text { Squares }\end{array}$} & df & \multicolumn{1}{c|}{$\begin{array}{c}\text { Mean } \\
\text { Square }\end{array}$} & F & Sig. \\
\hline & Regression & 524.494 & 3 & 174.831 & 57.445 & $.000^{\mathrm{a}}$ \\
1 & Residual & 249.565 & 82 & 3.043 & & \\
& Total & 774.058 & 85 & & & \\
\hline
\end{tabular}

a.Predictors: (Constant), X3, X1, X2

b.Dependent Variable: Y

Source: Data processed by SPSS version 20.0 (2020)

The table above shows that the calculated $\mathrm{F}$ value is 57.445 with a probability of 0.000 , because the significance is less than 0.05 , the regression model can be used to predict customer loyalty. This can also be seen 
From $F_{\text {count }}>F_{\text {table }}(57.445>2.48)$, then Ho is rejected or Ha is accepted, which means that there is a significant positive effect simultaneously of sales promotion variables, product quality and customer satisfaction together on customer loyalty variables.

\section{b. Partial Hypothesis Testing (t test)}

Partial hypothesis testing $t$ test. The test results can be seen in the following table:

From the results of the t test above, it can be concluded that:

a. Coefficient for Sales Promotion

The value of $t_{\text {count }}>t_{\text {table }}(2.583>1.662)$ and a probability value of $0.012>0.05$, then Ha is accepted, which means that there is a positive influence from the sales promotion variable on customer loyalty at PT. Salim Jaya Medan.

b. Coefficient for Product Quality

The value of $t_{\text {count }}>t_{\text {table }}(3.044>1.662)$ and a probability value of $0.003<0.05$, then Ha is accepted, which means that there is a significant positive effect of the product quality variable on customer loyalty at PT. Salim Jaya Medan

c. Coefficient for customer satisfaction

The value of $t_{\text {count }}>t_{\text {table }}(6.998>1.662)$ and the probability value of $0.000<0.05$, then $\mathrm{Ha}$ is accepted, which means that there is a significant positive effect of the customer satisfaction variable on customer loyalty at PT. Salim Jaya Medan.

\section{c. The Coefficient of Determination}

The following is the value of the correlation coefficient and determination obtained from the results of data testing:

Table 7. Coefficient of Determination (R2)

\begin{tabular}{|r|c|r|r|c|c|}
\hline Model & $\mathrm{R}$ & $\begin{array}{c}\mathrm{R} \\
\text { Square }\end{array}$ & $\begin{array}{c}\text { Adjusted R } \\
\text { Square }\end{array}$ & $\begin{array}{c}\text { Std. Error } \\
\text { of the Estimate }\end{array}$ & $\begin{array}{c}\text { Durbin- } \\
\text { Watson }\end{array}$ \\
\hline 1 & $.823^{\mathrm{a}}$ & .678 & .666 & 174.455 & 2.346 \\
\hline
\end{tabular}

a.Predictors: (Constant), X3, X1, X2

b. Dependent Variable: Y

Source: Data processed by SPSS version 20.0 (2020)

Based on the coefficient of determination ( $R$ Square), it can be concluded that customer loyalty is influenced jointly by sales promotion, product quality and customer satisfaction by 0.678 or $67.8 \%$ at PT. Salim Jaya Medan, while the remaining $32.2 \%$ is influenced by other factors outside of this study.

\subsection{Discussion}

a. The Effect of Sales Promotion on Customer Loyalty

Based on hypothesis testing that has been done, partially sales promotion has a significant positive effect on customer loyalty at PT. Salim Jaya Medan. This can be seen from the value of tcount $>$ ttable $(2.583>1.662)$ and the probability value of $0.012>0.05$, then $\mathrm{Ha}$ is accepted, which means that there is a positive effect of the sales promotion variable on customer loyalty at PT. Salim Jaya Medan.

The results of this study are in line with the research of Dezil, Yasri, Abror (2012). With the title The Influence of Service Quality, Sales Promotion, and Location on Customer Loyalty at PT. Bank Rakyat Indonesia (Persero), Tbk Unit Kodya I Padang Panjang which proves that service quality, sales promotion, and location have a significant effect on customer loyalty. 


\section{b. Effect of Product Quality on Customer Loyalty}

Based on hypothesis testing that has been done, partially product quality has a significant positive effect on customer loyalty at PT. Salim Jaya Medan. This can be seen from the value of tcount $>$ ttable $(3.044>1.662)$ and the probability value of $0.003<0.05$, then $\mathrm{Ha}$ is accepted, which means that there is a significant effect of the sales promotion variable on customer loyalty at PT. Salim Jaya Medan.

The results of this study are in line with the research of Dennisa and Santoso (2016) with the title analysis of the effect of product quality, service quality and brand image on customer loyalty at the Cosmetic Beauty Clinic in Semarang which proves that partially, customer satisfaction has a positive and significant effect on customer loyalty at the Cosmetic Beauty Clinic. This influence indicates that the higher the customer satisfaction, the higher the customer loyalty.

\section{c. The Influence of Customer Satisfaction on Customer Loyalty}

Based on hypothesis testing that has been done, partially customer satisfaction has a significant positive effect on customer loyalty at PT. Salim Jaya Medan. This can be seen from the value of $t_{\text {count }}>t_{\text {table }}(6.998>1.662)$ and the probability value of $0.000<0.05$, then $\mathrm{Ha}$ is accepted, which means that there is a significant positive effect of the variable customer satisfaction on customer loyalty at PT. Salim Jaya Medan.

The results of this study are in line with Rachmawati's (2010) study entitled The Influence of Customer Satisfaction on Customer Loyalty (A Study on the Food Business) which proves that customer satisfaction variables affect customer loyalty.

\section{d. Effect of Sales Promotion, Product Quality and Customer Satisfaction on Customer Loyalty}

Based on the hypothesis testing that has been done, simultaneously sales promotion and customer satisfaction have a significant positive effect on customer loyalty at PT. Salim Jaya Medan. This can be seen from the value of $F_{\text {count }}>F_{\text {table }}(57.445>2.48)$, then Ha is accepted, which means that there is a significant positive effect simultaneously of the sales promotion variable and customer satisfaction together on the customer loyalty variable.

The strong relationship between sales promotions, product quality and customer satisfaction with customer loyalty is shown by the correlation coefficient value of 0.823 which indicates a strong level of relationship. Based on the coefficient of determination $(R$ Square) it can be concluded that customer loyalty is influenced jointly by sales promotion, product quality and customer satisfaction of 0.678 or $67.8 \%$ at PT. Salim Jaya Medan while the remaining $32.2 \%$ is influenced by other factors.

\section{Conclusion}

After analyzing the data obtained, the researchers concluded the research results as follows:

1. The test results of the effect of sales promotions on customer loyalty at PT. Salim Jaya Medan (Frozen Food Distribution Case Study) shows that sales promotion partially has a positive effect on customer loyalty, with a tcount of 2,583 greater than the ttable value of 1,662 .

2. The results of testing the effect of product quality on customer loyalty at PT. Salim Jaya Medan (Frozen Food Distribution Case Study) shows that the product quality partially has a positive and significant effect on customer loyalty, with a tcount value of 3.044 greater than the ttable value of 1.662 . 
3. The test results of the influence of customer satisfaction on customer loyalty at PT. Salim Jaya Medan (Frozen Food Distribution Case Study) shows that partially customer satisfaction has a positive and significant effect on customer loyalty, with a t-count value of 6,998 greater than the t-table value of 1,662 .

4. Simultaneous test results, sales promotion, product quality and customer satisfaction have a significant positive effect on customer loyalty at PT. Salim Jaya Medan. This can be seen from the value of Fcount $>$ Ftable $(57,445>2.48)$. Based on the coefficient of determination ( $\mathrm{R}$ Square) it can be concluded that customer loyalty is influenced jointly by sales promotion, product quality and customer satisfaction of 0.678 or $67.8 \%$ at PT. Salim Jaya Medan while the remaining 32.2\% is influenced by other factors outside of this study.

\section{Suggestion}

The following are suggestions based on research results:

1. PT. Salim Jaya Medan is expected to continue to improve sales promotion, product quality and customer satisfaction by continuing to be active in customer loyalty.

2. The results of this study are expected to be a reference or research material for future researchers who will conduct research in other companies.

3. Future research is expected to add variables to future studies in order to strengthen or compare research assumptions and obtain better results.

\section{References}

Abdurrahman, Nana Herdiana. (2015). Manajemen Strategi Pemasaran. Bandung: CV. Pustaka Setia.

Andi. Siregar, Syofian. (2014). Metode Penelitian Kuantitatif: Dilengkapi dengan Perbandingan Perhitungan Manual \& SPSS. Cetakan Kedua. Jakarta: Penerbit Kencana, Prenadamedia Group.

Anoraga, Pandji. (2009). Manajemen Bisnis. Cetakan Keempat. Jakarta: Rineka Cipta.

Arikunto, Suharsimi. (2010). Prosedur Penelitian - Suatu Pendekatan Praktik.Jakarta: Rineka Cipta.

Daryanto dan Setyabudi, Ismanto. (2014). Konsumen dan Pelayanan Prima. Yogyakarta: Gava Media.

Ginting, Nembah F. Hartimbul. (2011). Manajemen Pemasaran. Bandung: Yrama Widya.

Hasan, Ali. (2013). Marketing dan Kasus-Kasus Pilihan. Cetakan Pertama. Yogyakarta: CAPS.

Herlambang, Susatyo. (2014). Basic Marketing (Dasar-dasar Pemasaran) Cara Mudah Memahami Ilmu Pemasaran. Yogyakarta: Gosyen Publishing.

Magdalena, S,. and Suhatman,, R. (2020). The Effect of Government Expenditures, Domestic Invesment, Foreign Invesment to the Economic Growth of Primary Sector in Central Kalimantan. Budapest International Research and Critics Institute-Journal (BIRCI-Journal).P. 1692-1703

Manullang, M. (2013). Pengantar Bisnis. Jakarta: PT. Indeks.

Misbahuddin dan Hasan, Iqbal. (2013). Analisis Data Penelitian dengan Statistik.Edisi Kedua. Jakarta: Bumi Aksara.

Neolaka, Amos. (2014). Metode Penelitian dan Statistik untuk Perkuliahan, Penelitian Mahasiswa Sarjana, dan Pascasarjana. Bandung: Remaja Rosdakarya. 
Priyatno, Duwi. (2010). Paham Analisa Statistik Data dengan SPSS. Yogyakarta: Penerbit MediaKom.

Priyatno, Duwi. (2014). SPSS 22: Pengolah Data Terpraktis. Yogyakarta: Penerbit Andi.

Rahmayanty, Nina. (2010). Manajemen Pelayanan Prima. Yogyakarta: Graha Ilmu.

Romdonny, J. et al. (2019). Factors Affecting Customer Loyalty in Products. Budapest International Research and Critics Institute-Journal (BIRCI-Journal). P. 337-343.

Rosmika,T., E. et al. (2019). The Role of BRI Bank Medan Perjuangan Unit for Customer's Households, Indonesia. Budapest International Research and Critics Institute-Journal (BIRCI-Journal). P. 363-374.

Sangadji, Etta Mamang dan Sopiah. (2010). Metodologi Penelitian: Pendekatan Praktis dalam Penelitian. Yogyakarta: Penerbit Andi.

Sangadji, Etta Mamang dan Sopiah. (2013). Perilaku Konsumen Pendekatan Praktis Disertai: Himpunan Jurnal Penelitian. Yogyakarta: Penerbit

Sugiyono. (2012). Metode Penelitian Pendidikan Pendekatan Kuantitatif, Kualitatif, dan R\&D. Bandung: Alfabeta.

Sujarweni, V. Wiratna. (2014). SPSS untuk Penelitian. Cetakan Pertama. Yogyakarta: Pustaka Baru Press.

Suryabrata, Sumadi. (2013). Metodologi Penelitian. Cetakan Kedua Puluh Empat. Jakarta: PT. Raja GrafindoPersada.

Tjiptono, Fandy. (2008). Strategi Pemasaran. Edisi Ketiga. Yogyakarta: Penerbit Andi.

Widiana, Muslichah Erma. (2010). Dasar-dasar Pemasaran. Bandung: Karya Putra Darwati.

Wood, Marian Burk. (2009). Buku Panduan Perencanaan Pemasaran. Edisi Ketiga. Jakarta: Indeks. 